\title{
The Analysis of Covid-19 Knowledge of Health Sciences Students Based on Their Characteristics
}

\author{
Retno Widowati ${ }^{1,2 *}$, Triana Indrayani ${ }^{2}$, Rukmaini ${ }^{2}$ \\ ${ }^{\text {I} B i o l o g y ~ M a s t e r s ~ P r o g r a m ~-~ U n i v e r s i t a s ~ N a s i o n a l, ~ J a k a r t a, ~ I n d o n e s i a ~}$ \\ ${ }^{2}$ Faculty of Health Sciences - Universitas Nasional, Jakarta, Indonesia \\ *retno.widowati@civitas.unas.ac.id
}

\begin{abstract}
The study was an observational study with a cross sectional approach, snowball sampling, using a questionnaire distributed online to health science students, for 4 days. The questionnaire contained informed consent, five questions related to respondent characteristics, and 20 questions sourced from WHO. Analysis of the results is done by calculating the frequency distribution and chi square test to see the relationship of knowledge about COVID-19 with student characteristics.

A total of 538 people were respondents in this study. The median knowledge of respondents was 37 and $71 \%$ of respondents had good knowledge. Respondents came from Nursing, Midwifery and Nursing Professional Education study programs. As many as $61.3 \%$ of students work as health workers. The respondent's province of residence consists of 19 provinces in Indonesia. Respondents aged <20 years to > 40 years, most 45.7\% aged 20-25 years. The three most common sources of information COVID-19 are the internet $37 \%$, television $25.3 \%$ and superiors and colleagues at work $19.7 \%$. Cumulative Achievement Index (IPK) between 3.0 - 3.5 is the most IPK of respondents (59.7\%). Median knowledge scores 37 and $71 \%$ of respondents have good knowledge.

There was a significant relationship $(\mathrm{p}<0.05)$ between COVID-19 knowledge and the student's employment status, study program and health science student age. There is no meaningful relationship between COVID-19 knowledge with the province of residence, the IPK, the source of information.
\end{abstract}

Keywords : COVID-19, Student of Health Sciences, Knowledge 


\section{STRADA Jurnal Ilmiah Kesehatan}

DOI: $10.30994 /$ sjik.v9i2.348

ISSN: 2252-3847 (print); 2614-350X (online)

Vol.9 No.2 November 2020 Page.619-628

\section{BACKGROUND}

Coronavirus Disease 2019 (COVID-19) has become a world health problem. This case began with the information from the World Health Organization (WHO) on December 31, 2019 which mentioned a case of pneumonia cluster with an unclear etiology in Wuhan City, Hubei Province, China. This case continues to grow until there are reports of deaths and imports occur outside of China. On January 30, 2020, WHO established COVID-19 as the Public Health Emergency of International Concern/The World's Worst Public Health Emergency. On February 12, 2020, WHO officially designated this human novel coronavirus disease as Coronavirus Disease (COVID19). On March, 11, 2020, WHO established COVID-19 as a pandemic (Indonesian Ministry of Health, 2020).

In a short time, COVID-19 spreads to 166 countries in the world and has caused at least 14.705 deaths in the world and 49 deaths in Indonesia until March 23, 2020. The rapid spread of viruses and the addition of victims have become the focus of all levels of society and the Indonesian government. In response to this, the Indonesian government swiftly take strategical steps in mutual cooperation through preparing and strengthening the capacity of health resources both in hospitals, laboratories, and other health facilities (Task Force for the Acceleration of Handling COVID-19, 2020).

Data obtained from the Kompas daily on April 20, 2020 states that until April 19, 2020 at 12.00, 29 doctors and 15 nurses died as health workers in the middle of the COVID-19 Pandemic. Refering to Director of National Hospital Infection Management and Quality Control in China - there are several reasons for the large number of infected health workers, one of which is inadequate personal protection of health workers at the start of the epidemic which became a major problem. In fact, they did not understand the pathogens well and their awareness of personal protection was not strong enough (Wang et al., 2020). This shows the importance of knowledge for health workers as well as students or prospective health workers.

COVID-19 is a topic of global discussion in the media and among the public, which also raises tension for everyone, including the health officials. This raises repeated questions about how to manage information to help the frontline health workers in times of public health crisis (Bhagavathula et al., 2020). Public knowledge and attitudes are expected to influence the level of adherence to personal protection measures and ultimately, clinical outcomes (Ebrahim et al., 2020). Health education is also very important to be given to create awareness during epidemic and pandemic situations for effective prevention of the spread of disease (Johnson and Hariharan, 2017).

Adding and updating knowledge are very important for health workers. As stated by Asemahagn (2014) that health professionals need the latest health information from reliable sources to increase their knowledge and provide health care services. In fact, health workers who are at risk of infection in epidemic chains becomes a critical problem as they help to control the outbreaks (Zhou et al., 2020). Minimal understanding of the disease among health workers can have implications for late treatment and rapid spread of infection (Bhagavathula et al., 2020).

Based on the above explanation, this study aims to analyze the knowledge of COVID-19 based on the characteristics of Health Sciences students.

\section{METHODS}

The design of this study is an observational research with cross sectional approach. The research instrument used was a questionnaire containing informed consent, respondent characteristics and knowledge questions of 20 items with true and false answers. The 


\section{STRADA Jurnal Ilmiah Kesehatan}

DOI: $10.30994 /$ sjik.v9i2.348

ISSN: 2252-3847 (print); 2614-350X (online)

Vol.9 No.2 November 2020 Page.619-628

questionnaire only takes 5 minutes to be fully answered. Characteristics of respondents are in the form of (information related to) study program origin, province of residence when filling out the questionnaires, employment status, age, the most sources of information about COVID-19, and Grade Point Average (GPA) of the previous semester. The sources of the questionnaire items were from WHO Questions and Answers related to Coronavirus on the WHO home page (2020).

Questionnaire items were grouped into several topics namely viruses that cause COVID-19 (5 questions), treatment and vaccines (4 questions), virus spread (4 questions), COVID-19 symptoms (3 questions), prevention (3 questions), as well as pandemic and incubation which serve respectively 1 question each. All questions are in the form of True or False answers. Correct answer is given a value of 2 and incorrect answer is given a value of 1 .

Questionnaire was typed in a google docs form with a link: https://forms.gle/rxTyv45PPea8bMMC8 and disseminated to all active students in the even semesters of the academic year 2019/2020 at the Faculty of Health Sciences in Universitas Nasional, using WhatsApp social media. Data collection was conducted from April, 28 to May, 2, 2020.

\section{Research Ethics}

The confidentiality of research participant information was maintained throughout the study by making the participant information anonymous. Surveys were voluntary.

\section{Data analysis}

Good and insufficient knowledge is determined by the median of all respondents' values. Knowledge is considered as good if it is equal to or greater than the median. Knowledge is considered to be lacking (insufficient) if it is less than the median (Manikandan, 2011). Descriptive analysis was done using frequency and proportion. Bivariate analysis with chi square test was used/applied to see the relationship or association of respondents' characteristics with knowledge at the level of $p<0.05$. Data were collected using SPSS version 20 (IBM, Armonk, NY, USA).

\section{RESULTS AND DISCUSSION \\ The characteristics of the respondents}

A total of 538 people were respondents in this study. Statistical test results show that the median value of knowledge is 37 . There are $156(29 \%)$ of respondents who are lack in knowledge and $382(71 \%)$ of respondents who have good knowledge. Of all respondents, $196(36.4 \%)$ are unemployed students; $330(61.3 \%)$ of them work as health workers, and $12(2.2 \%)$ work not as health workers. As many as $376(69.9 \%)$ respondents are students of the Midwifery Study Program; 131 (24.3\%) respondents are students of the Nursing Study Program; and 31 (5.8\%) respondents are students of the Nurse Professional Education Study Program (Table 1).

Of the 19 provinces where the respondents live, the top five provinces of where the respondents live are Banten 206 (38.3\%), West Java 157 (29.2\%), DKI Jakarta 85 (15.8\%), Maluku $24(4.5 \%)$ and Southeast Sulawesi 23 (4.3\%). In addition, 38 (7.1\%) come from Lampung 9 (1.7\%); South Sumatra $8(1.5 \%)$; $5(0.9 \%)$ of each West Sumatra and Bangka Belitung Islands; North Sumatra 4 (0.7\%); East Nusa Tenggara $3(0.6 \%)$; DI Yogyakarta $2(0.4 \%)$ and Jambi, Central Java, East Java, West Kalimantan, South Kalimantan, North Maluku, Papua which each have 1 (0.2\%) student (Table 1). 


\section{STRADA Jurnal Ilmiah Kesehatan}

DOI: $10.30994 /$ sjik.v9i2.348

ISSN: 2252-3847 (print); 2614-350X (online)

Vol.9 No.2 November 2020 Page.619-628

Age of the respondents range from $<20$ y.o to $>40$ y.o. Most age groups are between above $20-25$ y.o which is as many as $247(45.9 \%)$; followed by under 20 y.o which is 65 (12.1\%); age above $25-30$ y.o is $48(8.9 \%)$; age above $30-35$ y.o is 61 $(11.3 \%)$; age over $35-40$ y.o is $60(11.2 \%)$; and age over 40 y.o is $57(10.6 \%)$ (Table 1$)$.

The respondents mostly get the most information about COVID-19 from the internet $37 \%$, television $25.3 \%$ as well as superiors and colleagues at work $19.7 \%$. Others (information) come from other social media like Instagram 5.6\%; WhatsApp 5.4\% and Facebook $1.9 \%$, from lecturers and mass media respectively is $1.3 \%$. Other sources of information are as many as $14(2.6 \%)$ (Table 1). Grade Point Average (GPA) is a measure of a student ability up to a certain period and- calculated based on the number of credits (semester credit units). Student GPA in the previous semester are: GPA of $<3$ is as many as $68(12.6 \%)$; GPA of $3.0-3.5$ is as many as $321(59.7 \%)$ and GPA of $>3.5$ is as many as $149(27.7 \%)$. The distribution and percentage of GPA of the student respondents are presented in Table 1.

Table 1. The frequency and percentage of characteristics and status of the student respondents

\begin{tabular}{|c|c|c|c|c|c|c|c|c|c|}
\hline \multirow{4}{*}{ Characteristics } & \multirow{4}{*}{$\begin{array}{l}\text { Distinguishing } \\
\text { Items }\end{array}$} & \multicolumn{6}{|c|}{ Student Status } & & \multirow{3}{*}{ Total } \\
\hline & & \multicolumn{4}{|c|}{$\begin{array}{l}\text { Does not work Work as a } \\
\text { Health Worker }\end{array}$} & \multicolumn{2}{|c|}{$\begin{array}{l}\text { Work Not as a } \\
\text { Health Worker }\end{array}$} & & \\
\hline & & 196 & $36.4 \%$ & 330 & $61.3 \%$ & 12 & $2.2 \%$ & & \\
\hline & & $\mathrm{f}$ & $\%$ & $\mathrm{f}$ & $\%$ & $\mathrm{f}$ & $\%$ & $\mathrm{~F}$ & $\%$ \\
\hline \multirow{2}{*}{$\begin{array}{l}\text { Knowledge } \\
(\mathrm{n}-538)\end{array}$} & Good/Well & 123 & 32.2 & 249 & 65.2 & 10 & 2.6 & 382 & 71.0 \\
\hline & Less/Insufficient & 73 & 46.8 & 81 & 51.9 & 2 & 1,3 & 156 & 29.0 \\
\hline \multirow{4}{*}{$\begin{array}{l}\text { Study } \\
\text { program } \\
(\mathrm{n}=538)\end{array}$} & Nursing & 104 & 79.4 & 23 & 17.6 & 4 & 3.10 & 377 & 69.9 \\
\hline & Midwifery & 91 & 24.2 & 287 & 73.9 & 7 & 1.90 & 131 & 24.3 \\
\hline & $\begin{array}{l}\text { Nurse professiona } \\
\text { education }\end{array}$ & & 3,2 & 29 & 93.5 & 1 & 1.90 & 31 & 5.8 \\
\hline & $\mathrm{X} 2(4)$ & \multicolumn{6}{|c|}{$147,848 * * *$} & & \\
\hline \multirow{7}{*}{$\begin{array}{l}\text { Province of } \\
\text { residence } \\
(\mathrm{n}=533)\end{array}$} & Banten & 28 & 13.6 & 175 & 85.0 & 3 & 1.50 & 206 & 38.2 \\
\hline & West Java & 80 & 51.0 & 70 & 44.6 & 7 & 4.5 & 157 & 29.2 \\
\hline & DKI Jakarta & 63 & 74.1 & 21 & 24.7 & 1 & 1.20 & 85 & 15.8 \\
\hline & Maluku & 1 & & 23 & 95.8 & 0 & 0 & 24 & 4.5 \\
\hline & Southeast Sulawes & & 4,3 & 21 & 91.3 & 1 & 4.30 & 23 & 4,3 \\
\hline & Other provinces & 18 & 47.4 & 20 & 52.6 & 0 & 0 & 38 & 7,1 \\
\hline & $\mathrm{X} 2(10)$ & \multicolumn{6}{|c|}{$146,444 * * *$} & & \\
\hline$\overline{\text { Age (y.o) }}$ & $\leq 20$ & 65 & 100 & 0 & 0 & 0 & 0 & 65 & 12.1 \\
\hline \multirow[t]{6}{*}{$(\mathrm{n}=538)$} & $>20-25$ & 122 & 49.4 & 116 & 47.0 & 9 & 3,6 & 247 & 45.9 \\
\hline & $>25-30$ & 7 & 14.6 & 38 & 79.2 & 3 & 6.3 & 48 & 8.9 \\
\hline & $>30-35$ & 1 & 1.6 & 60 & 98.4 & 0 & 0 & 61 & 11.3 \\
\hline & $>35-40$ & 0 & 0 & 60 & 100.0 & 0 & 0 & 60 & 11.2 \\
\hline & $>40$ & 1 & 1, & 56 & 98.2 & 0 & 0 & 57 & 10.6 \\
\hline & $\mathrm{X} 2(10)$ & \multicolumn{6}{|c|}{$251,416 * * *$} & & \\
\hline \multirow{2}{*}{$\begin{array}{l}\text { The most } \\
\text { sources of }\end{array}$} & Internet & 99 & 49.7 & 92 & 46.2 & 8 & 4.0 & 199 & 37.0 \\
\hline & Television & 57 & 41.9 & 78 & 57.4 & 1 & 0.7 & 136 & 25.3 \\
\hline
\end{tabular}




\section{STRADA Jurnal Ilmiah Kesehatan}

DOI: $10.30994 /$ sjik.v9i2.348

ISSN: 2252-3847 (print); 2614-350X (online)

Vol.9 No.2 November 2020 Page.619-628

\begin{tabular}{|c|c|c|c|c|c|c|c|c|c|}
\hline \multirow[t]{8}{*}{$\begin{array}{l}\text { information } \\
(\mathrm{n}=538)\end{array}$} & $\begin{array}{l}\text { Superiors and } \\
\text { Colleagues at wor }\end{array}$ & 1 & 0.9 & 104 & 98.1 & 1 & 0.9 & 106 & 19.7 \\
\hline & Instagram & 18 & 60.0 & 12 & 40.0 & 0 & 0 & 30 & 5.6 \\
\hline & WhatsApp & 3 & 10.3 & 24 & 82.8 & 2 & 6.9 & 29 & 5,4 \\
\hline & Facebook & 1 & 10.0 & 9 & 90.0 & 0 & 0 & 10 & 1.8 \\
\hline & Lecturer & 6 & 85.7 & 1 & 14.3 & 0 & 0 & 7 & 1,3 \\
\hline & Massmedia & 1 & 14.3 & 6 & 85.7 & 0 & 0 & 7 & 1,3 \\
\hline & $\begin{array}{l}\text { Other sources of } \\
\text { information }\end{array}$ & 10 & 71.4 & 4 & 28.6 & 0 & 0 & 14 & 2.6 \\
\hline & X2 (16) & \multicolumn{8}{|c|}{$121,550 * * *$} \\
\hline$\overline{\mathrm{GPA}}$ & $<3.0$ & 13 & 19.1 & 55 & 80.9 & 0 & 0 & 68 & 12.6 \\
\hline \multirow[t]{3}{*}{$(n=538)$} & $\geq 3.0-3.5$ & 105 & 32.7 & 208 & 64.8 & 8 & 2.5 & 321 & 59.7 \\
\hline & $>3.5$ & 78 & 52.3 & 67 & 45.0 & 4 & 2.7 & 149 & 27.7 \\
\hline & $\mathrm{X} 2(4)$ & \multicolumn{8}{|c|}{$303,303 * * *$} \\
\hline
\end{tabular}

Note $* * *:<0.001$

\section{The relationship of employment status with COVID-19 knowledge}

The results of the relationship analysis between the employment status of respondents and the knowledge of COVID-19 are presented in the table 2. The results show that there is a significant relationship between the employment status of all respondents $(n=538)$ and the knowledge of COVID-19 $(0.005<0.05)$. This is in accordance with a study conducted by Roy et al. (2020) which states that educated people and health workers are more sensitive to information about COVID-19, even these respondents have a moderate level of awareness about the mode of transmission, symptoms, and adequate awareness of COVID-19 preventive measures. The relationship of knowledge and the student status was also investigated by Chilton et al. (2016) on licensed nursing students who have higher knowledge of Ebola Virus Disease compared to those who have not been licensed. Anjum et al. (2005) states that there are significant differences between preclinical and clinical students regarding knowledge of medical/surgical procedures that cause infections and ways to protect against HIV/AIDS. COVID-19 knowledge studies also differed significantly in mental labor compared to students (Zhong et al., 2020).

The health sciences students who have worked in the health field have better knowledge compared to the health sciences students who do not work or work not in the health field. Knowledge of COVID-19 is considered to be very important for health workers to in order to be able to explain to the public, patients and patients' families, and to maintain their personal safety so as not to be infected with COVID-19. This is in accordance with a study conducted on health workers from February, 4 - 8, 2020 involving 1357 health workers from 10 hospitals in Henan China - the survey results states that $89 \%$ of health workers have sufficient knowledge about COVID-19 (Zou et al, 2020 ) 


\section{STRADA Jurnal Ilmiah Kesehatan}

DOI: $10.30994 /$ sjik.v9i2.348

ISSN: 2252-3847 (print); 2614-350X (online)

Vol.9 No.2 November 2020 Page.619-628

Table 2. The relationship of the respondent characteristics with COVID-19

knowledge

\begin{tabular}{llc}
\hline Characteristics & $\mathbf{X}^{\mathbf{2}}$ & $\mathbf{p}$ \\
\hline $\begin{array}{l}\text { Respondents from All Study Programs } \\
(\mathbf{n}=\mathbf{5 3 8})\end{array}$ & $\begin{array}{l}10,539 \\
(\mathrm{df}=2)\end{array}$ & 0.005
\end{tabular}

Does not work

Work as a health worker

Work not as a health worker

\begin{tabular}{lll}
\hline $\begin{array}{l}\text { Study Program }(\mathbf{n}=\mathbf{5 3 8}) \\
\begin{array}{l}\text { Nursing } \\
\text { Midwifery }\end{array}\end{array}$ & $\begin{array}{l}9,690 \\
(\mathrm{df}-2)\end{array}$ & 0.008 \\
Nurse Professional Education & & \\
\hline $\begin{array}{l}\text { Province of residence }(\mathbf{n}=\mathbf{5 3 3}) \\
\text { Banten }\end{array}$ & $\begin{array}{l}7,518 \\
(\mathrm{df}=5)\end{array}$ & .185
\end{tabular}

West Java

DKI Jakarta

Maluku

Southeast Sulawesi

Other provinces

$\begin{array}{lll}\text { The Most Sources of Information }\left(\mathbf{n}=\begin{array}{l}9,457 \\ (\mathrm{df}=8)\end{array}\right. & 0.305 \\ \mathbf{5 3 8})\end{array}$

Internet

Television

Superiors and Colleagues at work

Instagram

WhatsApp

Facebook

Lecturer

Massmedia

Other sources of information

\begin{tabular}{lll}
\hline GPA $(\mathbf{n}=\mathbf{5 3 8})$ & $\begin{array}{l}4,729 \\
(\mathrm{df}=2)\end{array}$ & 0.094 \\
$<3,0$ & & \\
$\geq 3.0-3.5$ & & \\
$>3.5$ & 17,217 & 0.004 \\
\hline Age $(\mathbf{n}=\mathbf{3 5 8})$ & $(\mathrm{df}=5)$ & \\
$<20$ y.o & & \\
$>20-25$ y.o & & \\
$>25-30$ y.o & & \\
$>30-35$ y.o & & \\
$>35-40$ y.o & & \\
$>40$ y.o &
\end{tabular}

\section{The relationship of the respondents' study program with COVID-19 knowledge}

There is a significant relationship between the respondents' study program and COVID-19 knowledge $(p=0.008)<(\alpha=0.05)$ (Table 2). The percentage of the student respondents from the Midwifery Study Program have better results in knowledge compared to the student respondents from the Nursing Study Program and the Nurse 


\section{STRADA Jurnal Ilmiah Kesehatan}

DOI: $10.30994 /$ sjik.v9i2.348

ISSN: 2252-3847 (print); 2614-350X (online)

Vol.9 No.2 November 2020 Page.619-628

Professional Education Study Program. This is in line with a study on health science students in Iran in five fields of study on Hepatitis B and C, which states the study program is significantly related to the level of knowledge of respondents (Karimi-Sari et al., 2017).

\section{The relationship of the province of residence of the respondents with knowledge of COVID-19}

The results show that there is no relationship between the province of residence of the respondents with knowledge of COVID-19 ( $p>0.05$ ) (Table 2). This shows that wherever the responsidents' province of residence, both in the capital city of Indonesia, DKI Jakarta or its closest provinces, namely Banten and West Java, they provide more or less the same results to the knowledge of respondents whose residence in the provinces that are far from the capital of Indonesia like in Southeast Sulawesi and Maluku. Thus the residency does not limit the flow of information to obtain COVID-19 information in 19 provinces in Indonesia. Knowledge can be obtained from various means of information available, and in this day and age, information is very quickly obtained because the communication network is easily accessed.

This is different from a study by Karimi-Sari et al. (2017), which reveals that there is a significant relationship between the home province of health sciences students with the knowledge of Hepatitis B and C. In addition, COVID-19 knowledge of the residents in Hubei Province, which is the location of Wuhan city, also differs significantly from those who live in other provinces (Zhong et al., 2020).

\section{The relationship of the most sources of information with COVID-19 knowledge}

There is no significant relationship between the most sources of information and the respondents' COVID-19 knowledge ( $p>0.05$ ) (Table 2). All of the sources of information, including the internet, television, superiors and colleagues at work, various social media provide more or less the same information for the respondents. Information about official sources of information about COVID-19 is important to be socialized. This is to avoid the same phenomenon wherein many students $(43.8 \%)$ reported not knowing where to get accurate information about the Zika virus, in the results of the study after an outbreak of Zika virus infection in America (Plaster et al., 2018).

Information will influence someone's knowledge. Although a person has a low education, but if he gets good information from various media such as TV, radio or newspapers then - it will be able to increase one's knowledge (Hendra, 2008).

\section{The relationship of GPA with COVID-19 knowledge}

Grade Point Average (GPA) is a reflection of the results of learning outcomes at the end of the study program. GPA is highly correlated with declarative knowledge (Cox, 2019). Declarative knowledge is factual information that is known by someone or conceptual knowledge that is stored in long-term memory. This knowledge can be expressed both orally and in writing.

There is no significant relationship between the GPA of the students respondents and their COVID-19 knowledge ( $\mathrm{p}>0.05$ ) (Table 2). This is different from a study by Wicaksono (2012) which suggests that there is a significant relationship between GPA and Indonesian Doctor Competency Test scores. Natu's study (2018) also states that there is a significant relationship between the GPA and the national competency test $(\mathrm{P}=0.0001<\alpha$ $=5 \%$ ). These studies are also in accordance with a study by Utami et al. (2017) which 


\section{STRADA Jurnal Ilmiah Kesehatan}

DOI: $10.30994 /$ sjik.v9i2.348

ISSN: 2252-3847 (print); 2614-350X (online)

Vol.9 No.2 November 2020 Page.619-628

states that there is a significant relationship between the GPA of the professional stage with the progress test scores of the DPP (Dentist Profession Program) UMY students' professional stage from year 2006 to 2008 .

\section{The relationship between age and knowledge of COVID-19}

The breadth of the respondents' age category is because educational institutions accept students from high school graduates so that many of them have an age below 20 y.o. On the other hand, there are also educational institutions which accept advanced students from D III and- The Nurse Professional Education Program will cause students to be older than 25 y.o, even more than 40 y.o. Therefore, the age of the respondents has a fairly wide range.

There is a significant relationship between the age of the respondents with knowledge of COVID-19 $(p=0.008)<(\alpha=0.05)$ (Table 2$)$. Age in general will be in line with the increase in years of study in higher education, so that more knowledge is gained. Likewise, with regard to employment status, older students have more experience at work, so that their knowledge is also higher.

This is in line with other studies in which reveals that COVID-19 knowledge score differs significantly between age groups in the population in China, (Zhong et al., 2020). There is a significant relationship between the age of nursing students with Ebola Virus Disease knowledge (Chilton et al., 2016). In addition, there is also a significant relationship between student age with knowledge of hepatitis B and C (Ahmad et al., 2016; Gebremeskelet al., 2020; Khan et al., 2010).

\section{Research limitations}

This study used questions with resources that were developed from WHO about questions and answers related to coronavirus. This questionnaire has not been validated, but it is the second revised questionnaire to suppress the information bias of the questions.

Data is collected online and the data obtained is based on honesty with information from respondents. Some information may not be obtained optimally since the faculty has closed the second week of the lecture until the 16th week or the end of the semester.

\section{CONCLUSIONS}

There is a significant relationship ( $\mathrm{p}<0.05$ ) between COVID-19 knowledge and the Health Sciences students respondents' employment status, study program and age. There is no significant relationship COVID-19 knowledge and the province of residence, GPA, and the most sources of information about COVID-19.

\section{REFERENCES}

Ahmad, A., Munn Sann, L., \& Abdul Rahman, H. (2016). Factors associated with knowledge, attitude and practice related to hepatitis $\mathrm{B}$ and $\mathrm{C}$ among international students of Universiti Putra Malaysia. BMC public health, 16, 611. https://doi.org/10.1186/s12889-016-3188-5

Anjum Q, Siddiqui H, Ahmed Y, et al. (2005). Knowledge of students regarding hepatitis and HIV/AIDS of a private medical university in Karachi. Journal of Pakistan Medical Association. 2005;55:285-8. 


\section{STRADA Jurnal Ilmiah Kesehatan}

DOI: $10.30994 /$ sjik.v9i2.348

ISSN: 2252-3847 (print); 2614-350X (online)

Vol.9 No.2 November 2020 Page.619-628

Asemahagn, M.A. Knowledge and experience sharing practices among health professionals in hospitals under the Addis Ababa health bureau, Ethiopia. BMC Health Serv Res 14, 431 (2014). https://doi.org/10.1186/1472-6963-14-431

Bhagavathula, A.S., Aldhaleei, W.A., Rahmani, J., Mahabadi, M.A., Bandari, D.K. (2020). Novel Coronavirus (COVID-19) Knowledge and Perceptions: A Survey on Healthcare workers. doi:https://doi.org/10.1101/2020.03.09.20033381doi

Chilton, J.M., McNeill, C., Alfred D. (2016). Survey of Nursing Students' Self-Reported Knowledge of Ebola Virus Disease, Willingness to Treat, and Perceptions of Their Duty to Treat. Journal of Professional Nursing, Vol 32, No. 6: 487-493. https://doi.org/10.1016/j.profnurs.2016.05.004

Cox, Raymond. (2019). Re: Can I use student's CGPA/GPA (grades) as a proxy for declarative knowledge? . Retrieved from:

https://www.researchgate.net/post/Can_I_use_students_CGPA_GPA_grades_as_a proxy for_declarative knowledge/5cda417a36d2356a026f7b14/citation/download.

Ebrahim, S.H., Ahmed, Q.A., Gozzer, E., Schlagenhauf P., Memish, Z.A. (2020). Covid19 and community mitigation strategies in pandemic. British Medical Journal. 368:m1066. doi: https://doi.org/10.1136/bmj.m1066

Gebremeskel, T., Beshah, T., Tesfaye, M., Beletew, B., Mengesha, A., \& Getie, A. (2020). Assessment of Knowledge and Practice on Hepatitis B Infection Prevention and Associated Factors among Health Science Students in Woldia University, Northeast Ethiopia. Advances in preventive medicine, 2020, 9421964. https://doi.org/10.1155/2020/9421964

Gugus Tugas Percepatan Penanganan COVID-19 (2020). Pedoman Penanganan Cepat Medis Dan Kesehatan Masyarakat COVID-19 di Indonesia. https://www.covid19.go.id/wp-content/uploads/2020/04/Pedoman-PenangananCepat-Medis-dan-Kesehatan-Masyarakat-COVID-19-di-Indonesia.pdf

Hendra, AW. (2008). Faktor-Faktor Yang Mempengaruhi Pengetahuan, Jakarta : Pustaka Sinar. Harapan

Johnson, E.J., Hariharan, S. (2017). Public health awareness: knowledge, attitude and behaviour of the general public on health risks during the H1N1 influenza pandemic. Journal Public Health 25, 333-337 (2017). https://doi.org/10.1007/s10389-017-0790-7

Karimi-Sari H, Bayatpoor M, Khotbesara M, Ebrahimi M, Sattari Z, et al. (2017). Knowledge, attitude, and practice of Iranian health sciences students regarding hepatitis B and C viral infections: a national survey. American Journal of Infection Control . 2017;45:e135-e141. doi: 10.1016/j.ajic.2017.07.012.

Khan N., Ahmed S. M., Khalid M. M., Siddiqui S. H., Merchant A. A. (2010). Effect of gender and age on the knowledge, attitude, and practice regarding Hepatitis B and $\mathrm{C}$ and vaccination status of Hepatitis B among medical students of Karachi, Pakistan. Journal of the Pakistan Medical Association. 60(6):450-455.

Kementerian Kesehatan RI. (2020). Pedoman Kesiapsiagaan Menghadapi Coronavirus Disease (COVID-19) Revisi ke-3.

Kompas. 2020. Benahi Perlindungan terhadap Tenaga Kesehatan. Kompas, Senin, 20 April 2020. Halaman 1.

Natu, N., N. (2018). Faktor factor yang mempengaruhi ujian kompetensi D.III Keperawatan pada Politeknik Kesehatan Kemenkes Kupang Prodi Keperawatan Waingapu. Ethos. Jurnal Penelitian dan Pengabdian Kepada Masyarakat. Vol 6 No 2328 -335. DOI: $10.29313 /$ ethos.v6i2.3176 


\section{STRADA Jurnal Ilmiah Kesehatan}

DOI: $10.30994 /$ sjik.v9i2.348

ISSN: 2252-3847 (print); 2614-350X (online)

Vol.9 No.2 November 2020 Page.619-628

Plaster, A.N., Painter, J.E., Tjersland, D.H., Jacobsen K.H. (2018). University Students' Knowledge, Attitudes, and Sources of Information About Zika Virus. Journal Community Health 43(4):647-655. doi: 10.1007/s10900-017-0463-z.

Roy, D., Tripathy, S., Kar, S. K., Sharma, N., Verma, S. K., \& Kaushal, V. (2020). Study of knowledge, attitude, anxiety \& perceived mental healthcare need in Indian population during COVID-19 pandemic. Asian journal of psychiatry, 51, 102083. Advance online publication. https://doi.org/10.1016/j.ajp.2020.102083.

Utami, S., Kurniasih, I., Afiati, A.I. (2017). Hubungan Antara Nilai Progress Test Dengan Nilai Indeks Prestasi Kumulatif Lulusan Dokter Gigi Program Studi Pendidikan Profesi Dokter Gigi Universitas Muhammadiyah Yogyakarta. Insisiva Dental Journal, Vol. 6 No. 2: 33-39.

Wang W, Xu Y, Gao R, Lu., R, Han, K., Wu, G., Tan, W. 2020. Detection of SARS-CoV2 in Different Types of Clinical Specimens. Journal of American Medical Association. 2020;323(18):1843-1844. doi:10.1001/jama.2020.3786

Wang J, Zhou, M, Liu, F. (2020). Reasons for healthcare workers becoming infected with novel coronavirus disease 2019 (COVID-19) in China, Journal of Hospital Infection, https://doi.org/10.1016/j.jhin.2020.03.002

Wicaksono, A. (2012). Hubungan Antara Indeks Prestasi Kumulatif dan Nilai Uji Kompetensi Dokter Indonesia pada Dokter Lulusan Universitas Tanjungpura. Jurnal Visi Keilmuan. 7(1): 664-674.

Zhong, B.L., Lou, W., Li, H.M., Zhang, Q.Q., Liu X.G., Li, W.T., Li, Y. (2020). Knowledge, attitudes, and practices towards COVID-19 among Chinese residents during the rapid rise period of the COVID-19 outbreak: a quick online crosssectional survey. International Journal of Biological Sciences. 16(10): 1745-1752. doi: 10.7150/ijbs.45221.

Zhou M, Tang F, Wang Y, Nie H, Zhang L, You G, Zhang M. (2020). Knowledge, attitude and practice regarding COVID-19 among health care workers in Henan, China, Journal of Hospital Infection, https://doi.org/10.1016/j.jhin.2020.04.012.

WHO. (2020). https://www.who.int/indonesia/news/novel-coronavirus/qa-for-public diakses 20 Mei 2020 